\title{
Perception of Men Who Have Sex with Men about the Test and Treat Strategy of Human Immunodeficiency Virus in Bandung City
}

\author{
Ayesha Nadiatama Saifuddin, ${ }^{1}$ Nita Arisanti, ${ }^{2}$ Bony Wiem Lestari ${ }^{2}$ \\ ${ }^{1}$ Faculty of Medicine Universitas Padjadjaran, \\ ${ }^{2}$ Department of Public Health Faculty of Medicine Universitas Padjadjaran
}

\begin{abstract}
Background: Human immunodeficiency virus (HIV) infection in Indonesia has shifted from injecting drug use to sexual transmission. One of the ways to prevent HIV transmission is by using early antiretroviral therapy (ART) or known as Test and Treat. Test and Treat is recommended by the World Health Organization (WHO) in 2013. This study aimed to explore the perception of men who have sex with men (MSM) about HIV Test and Treat Strategy.

Methods: This quantitative observational study used a cross-sectional design. Primary data were collected from questionnaires filled in by 58 MSM diagnosed as HIV positive at Mawar Clinic, Pasundan and Ibrahim Adjie public health centers in September-December 2016. Sampling was performed using total sampling method which was bounded by time period. The questionnaire contained data of respondents' characteristics and perceptions of HIV Test and Treat Strategy. Data analysis was presented in tables.

Result: Respondents were mostly 20-24 years old (48\%), 55\% were Senior High School graduates, 98\% were unmarried, 58\% worked as employees, and 21\% earned 2-2.5 million rupiahs per month. Forty eight percent of the respondents had negative perception of the test and treat strategy, and $52 \%$ of the respondents had positive perception of the strategy.

Conclusions: Most of the MSM population have a negative perception of HIV test and treat strategy. It is important for the key populations especially the MSM to obtain education related to HIV treatments and strategy.
\end{abstract}

Keywords: Human immunodeficiency virus, men who have sex with men, perception, test and treat

\section{Introduction}

According to data from the World Health Organization (WHO) in 2014, there were 36.9 million of people in the world who lived with human immunodeficiency virus (HIV), out of which 34.3 million of them were adults, 17.4 million were women, and 2.6 million were children under 15 years of age. ${ }^{1}$

In Indonesia ${ }^{2}$, according to data from the Indonesian Ministry of Health from 1987 until December 2015, there were 191.073 people in HIV infection cases. If the people with HIV infection were classified based on provinces, West Java ranked in the fourth position with 17.679 people. If the people with HIV infection were grouped based on the risk factors, the most is heterosexuals, followed by others, then followed by men who have sex with men (MSM) with the percentage of $21.6 \%$, and the last is injecting drug users with $4.1 \%{ }^{2}$

From 2010 until 2015, the order of the most risk factors had been shifting from injecting drug use to sexual transmission especially in MSM which has increased by $28.1 \%{ }^{2}$

Men who have sex with men is a risk behavior and a precarious group towards HIV transmission sexually. ${ }^{3}$ One of the ways to prevent HIV transmission sexually is by giving antiretroviral (ARV) which was recommended by WHO in $2013 .{ }^{4}$ In accordance with the research of HIV Prevention Trials Network (HPTN) 052, providing an early ART reduce the risk of HIV sexual transmission to $96 \%$. The prevention of HIV transmission by providing ART is also called Test and Treat. ${ }^{5}$ Sexual transmission of HIV can also be prevented through the use of condoms; this can be seen from the research by Liu et al. $^{6}$ regarding the effectiveness of wearing condoms to prevent HIV sexual transmission

Correspondence: Ayesha Nadiatama Saifuddin, Faculty of Medicine, Universitas Padjadjaran, Jalan Raya BandungSumedang Km.21, Jatinangor, Sumedang, Indonesia, Email: ayeshanadiatamas@gmail.com 
within serodiscordant couples that couples who joined the antiretroviral therapy (ART) program have a declining risk of transmitting HIV for $67 \%$ and who joined the HIV program as well as wear condoms regularly can increase the protection level up to $99 \%$.

In Indonesia, the strategy of Test and Treat has not been implemented yet by healthcare facilities. According to the policy of the Indonesian Ministry of Health Regulation No. 21 Year 2013 about HIV/ Acquired Immunodeficiency Syndrome (AIDS) Prevention and policy No. 87 Year 2014 about the ARV Medication Guidance, ART will be given if the Cluster of Differentiation 4 (CD4) is less than or equal to 350 cell/ $\mathrm{mm}^{3}{ }^{7}$ Meanwhile, based on the WHO recommendation, the Test and Treat strategy has been applied in several countries as part of HIV transmission prevention. ${ }^{4}$ Due to the HIV sexual transmission increases for years and recently MSM is also a high risk factor, thus, this study aimed to identify the perception of the Test and Treat strategy on MSM population to give description in initiating the Test and Treat strategy in Indonesia.

\section{Methods}

This study was an observational quantitative study using cross-sectional design. The population of the study was men having sex with men (MSM) who lived in the city of Bandung. The subjects were MSM who were diagnosed HIV positive at Mawar Clinic, Pasundan and Ibrahim Adjie public health centers with the support and assistance of Abiasa non-governmental organization (NGO) in Bandung. The inclusion criterion of this study was MSM who were diagnosed with HIV, meanwhile, the exclusion criteria were MSM with severe illness, unwilling to participate in the study, and had the history of ARV (Antiretroviral) medication. The subjects were selected using the total sampling method that was bounded by time in the period of September-December 2016.

The data were collected by distributions of questionnaires with a structured interview. The questionnaire reference used was a questionnaire for doctors/physician in Massachusetts ${ }^{8}$ which had been modified and validated with Cronbach's Alpha of 0.867 . The total of questions in the questionnaire was 51 points, in which five points were about the respondents' characteristics and the other 46 points were questions about perceptions using Likert scale answer choices (Strongly agree,
Agree, Quite Agree, Quite Disagree, Disagree, and Strongly Disagree). The questions in the questionnaire were recited after gaining permission from the respondents. The respondents were introduced by the counselor and the workers at Abiasa NGO. Data collection was conducted from SeptemberDecember 2016 and was approved by the Health Research Ethics Committee, Faculty of Medicine, Universitas Padjadjaran with the letter No:518/UN6.C1.3.2/KEPK/PN/2016. The obtained data were then processed and analyzed using data processing software. The perception towards HIV Test and Treat strategy was categorized as positive by using data distribution test if the score result was $>160.2$, and if the score result was $<160.2$ then the perception of the respondents was categorized as negative.

\section{Results}

The number of respondents in this study was 58. The respondents were characterized in accordance with the age, the latest level of education, marital status, profession, and monthly income (Table 1).

In this study, the respondent's youngest age was 18 years and the oldest age was 46 years. The majority, $55 \%(n=32)$ of the respondents' level of education was senior high school graduates, $98 \%(n=57)$ of the respondents were unmarried, $58 \%(\mathrm{n}=34)$ worked as an employee and 21\% (n=12) earned Rp2-2.5 million per month (Table 1).

Respondents who had positive perception towards HIV Test and Treat Strategy were lower in percentage than respondents who had negative perception. The negative perception was higher by $4 \%$ (Table 2 ).

\section{Discussion}

This study discovered that the majority of respondents were $20-24$ years old (48\%). The median of the age in this study was 24 years. The highest number of respondents' level of education was senior high school (55\%). The majority of the respondents were unmarried (98\%).The majority of the respondents worked as employees (58\%). Similar findings can also be seen in a study conducted by Guadamuz, et al. ${ }^{9}$ about the characteristics of MSM who had not checked on HIV themselves yet, in the Association of South East Asian Nations (ASEAN); the majority of the respondents' age was $23-28$ years and $>28$ years or categorized 
Table 1 General Characteristics of Respondents

\begin{tabular}{|c|c|c|}
\hline Characteristics & Frequency (n) & Percentage (\%) \\
\hline \multicolumn{3}{|l|}{ Age } \\
\hline $15-19$ years & 6 & 10 \\
\hline 20-24 years & 28 & 48 \\
\hline $25-49$ years & 24 & $42 \%$ \\
\hline \multicolumn{3}{|l|}{ Level of Education } \\
\hline Never Get Formal Education & 0 & 0 \\
\hline Primary School & 0 & 0 \\
\hline Junior High School & 6 & 10 \\
\hline Senior High School & 32 & 55 \\
\hline Academy/University & 20 & 35 \\
\hline No Response & 0 & 0 \\
\hline \multicolumn{3}{|l|}{ Marital Status } \\
\hline Unmarried & 57 & 98 \\
\hline Married & 0 & 0 \\
\hline Divorced & 1 & 2 \\
\hline Divorced (because of death) & 0 & 0 \\
\hline \multicolumn{3}{|l|}{ Occupation } \\
\hline Employee & 34 & 58 \\
\hline Freelancer & 2 & 4 \\
\hline Student/College Student & 10 & 17 \\
\hline Unemployed & 0 & 0 \\
\hline No Response & 1 & 2 \\
\hline Others & 11 & 19 \\
\hline \multicolumn{3}{|l|}{ Monthly Income } \\
\hline No Income & 6 & 10 \\
\hline$<\operatorname{Rp} 500.000$ & 4 & 7 \\
\hline Rp500.000-1 Million & 9 & 16 \\
\hline Rp1 Million-1.5 Million & 6 & 10 \\
\hline Rp1.5 Million-2 Million & 5 & 9 \\
\hline Rp2 Million-2.5 Million & 12 & 21 \\
\hline Rp2.5 Million-3 Million & 2 & 3 \\
\hline >Rp3 Million & 8 & 14 \\
\hline Do not know & 2 & 3 \\
\hline No Response & 4 & 7 \\
\hline
\end{tabular}

in the productive period. While the majority of respondents had higher education and were university graduates. In addition, the majority of the respondents were unmarried, and had full-time jobs.

The results of the study revealed that the perception towards HIV Test and
Treat strategy was slightly negative (52\%) compared to the positive perception. However, most participants (95\%) responded that the information gained was adequate regarding the program. However, there were some respondents $(5 \%)$ who felt that information of the program regarding the objectives, benefits, 
Ayesha Nadiatama Saifuddin, Nita Arisanti, Bony Wiem Lestari: Perception of Men Who Have Sex with Men 527 about the Test and Treat Strategy of Human Immunodeficiency Virus in Bandung City

Table 2 Perception towards HIV Test and Treat Strategy

\begin{tabular}{lccc}
\hline & Perception & Frequency (n) & Percentage (\%) \\
\hline Positive & 28 & 48 \\
Negative & 30 & 52 \\
\hline
\end{tabular}

procedures, and advantages and disadvantages of the program was inadequate. All respondents were willing to join the program and acknowledged that the side effects of the medicines were really important to have prior discussions and to identify the opportunistic infections related to HIV. The majority of the respondents (97\%) considered the HIV Test and Treat program was positive and should be implemented in public health centers. This was shown in the study by Stringer, et al. ${ }^{10}$ about providing ART at primary services in Zambia, that the HIV AIDS services and providing ART at primary services could be implemented with good clinical results.

Some of the respondents (36\%) still wanted to try traditional medication, this showed that the respondents still lacked knowledge regarding ARV medicines and HIV. This finding was in line with the study by Tabi, et al. ${ }^{11}$ about the use of traditional and modern medications in Ghana, that to choose between tradition or modern medications was really influenced by the level of education, family, friends, faith and religion. This was also possibly caused by the time limitation of counselors to educate patients, due to the large number of patients and lacked of staff at the public health center. Almost a half of the respondents (47\%) were anxious about the side effects management if ARV medicines were provided in public health centers, and considered that the side effects management had to be provided in hospitals. Some respondents were also anxious about their obedience if ARV was given in public health centers, and $97 \%$ of the respondents thought that it would be better that every ARV taken in all HIV/AIDS services had to include the counseling process of compliance. Meanwhile, in the study conducted in Swaziland by Humphreys, et al. ${ }^{12}$ regarding ART given in the primary service and hospitals, it figured out that people who took ART in hospitals had more opportunities to skip an appointment with the therapist than those who took ART in the primary service. The majority (86\%) of the respondents was anxious about the interaction of ARV medicines with other medicines or alcohol; this is contrary to the study conducted by Shuaib, et al. ${ }^{13}$ regarding a survey towards patients who obtained warfarin therapy, about the medicine regiment knowledge, reveals that $56 \%$ do not acknowledge the interaction between medicines. More than a half of the respondents (69\%) were also anxious about being unable to take ARV medicines easily and regularly.

Most respondents (62\%) were anxious about their status if taking ARV medications at the public health center, and some respondents $(22 \%)$ were reluctant to take ARV at the public health center since they were afraid that their status would be noticed by people around them and thought that it would be better if ARV services were given in hospitals or special clinics. There were several respondents (45\%) who still felt that the stigma towards HIV is not decreasing. The findings in the study by Waluyo, et al. ${ }^{14}$ discovered that the stigma is still an issue in the society and this stigma is related to the level of information that the society have towards HIV/AIDS. The stigma influences one's optimum ability towards ARV therapy and the willingness to take the HIV test. Therefore, educating the society about HIV/ AIDS is very important to reduce the spread of stigma. Almost all respondents (83\%) were anxious that their status would be noticed by family, friends, or others in the community; meanwhile, the majority of the respondents $(78 \%)$ felt that the family's support was very important to encourage them to join the program. According to the study conducted by Shaluhiyah, et al. ${ }^{15}$ the stigma towards People with HIV/AIDS (PWHA) started from the family. The family who have negative perspectives towards PWHA will have greater probability to give stigma. Stigma towards PWHA will cause people with HIV feel alienated. The majority of the respondents (95\%) decided to start taking ARV medications and considered starting ARV medication in the near future. A rise in the willingness to undergo ARV treatment is a good thing, but the education about protected sex should be given. A study by Phillips AN, et al. ${ }^{16}$ discovered that there is a rise in ART but the number of unprotected sex has also increased.

Several respondents (33\%) were unwilling to consume ARV since they still did not accept the fact that they were infected by HIV, meanwhile, those who did not yet start the 
ARV medication due to the anxiety of the side effects were around $31 \%$ out of the total of the respondents. In addition, some respondents $(62 \%)$ were anxious about the examination cost of viral load and CD4 which became the constraint to get ARV.Some respondents (59\%) also addressed that the scheduled limitation of ARV taking at HIV/AIDS services which they visited would cause problems to obtain the medicines. Several respondents (12\%) felt healthy and did not need medication. Moreover, $65 \%$ of the respondents were anxious about the side effects of the medicines, and $64 \%$ were anxious that they could not work during ARV medication. Additionally, several respondents (5\%) were uncertain about the advantages of HIV medication, and 26\% of the respondents did not want to consume the pills every day. Those findings could influence an individual to start ARV medication. A study about ART and reasons of not consuming it in MSM population in Europe conducted by Marcus, et al. ${ }^{17}$ revealed that the common reasons $(88.8 \%$ out of 3259 respondents) for a person to stop consuming ARV and not to start ARV are that the person does not need the program, then followed by the fear of its consequences (11.7\%), and inability to access ART (2.3\%).

Based on the theory of Health Belief Model (HBM), behavior can change based on perception. A perception towards a disease can change someone's behavior if the performed behavior affects the health. ${ }^{18}$ In relation to it, then, somebody's perception is important to reduce risky behaviors to prevent HIV transmission. This is in line with the study by Mimiaga, et al. ${ }^{19}$, if someone is not precarious or exposed, they will not do screening. Therefore, education, information, and perception of somebody are important to reduce the HIV epidemic in Indonesia. The meta-analysis study by Crepaz, et al. ${ }^{20}$ revealed that most people with HIV positive is having a protected anal sex to protect partners. This behavioral change is possibly affected by the perception towards HIV.

This study has limitation of insufficient research time. Men who have sex with men is also a hidden population which made it difficult to get respondents, and the stigma towards HIV and MSM in society caused many respondents were not open with their status and were unwilling to be interviewed. The psychological condition of the respondents who only recently knew that they were HIV infected caused some respondents were unwilling to be interviewed since they were still shocked and were in the denial phase.
Generally, this study discovers that the perception of MSM population towards the strategic program of HIV Test and Treat is negative, especially regarding the statement of respondents' anxiety towards their HIV status which may be noticed by family, friends, or people in the community.

\section{References}

1. World Health Organization. HIV/AIDS data and statistics; [cited in 1 May 2016]; Available from: http://www.who.int/hiv/ data/en/

2. Kementrian Kesehatan Republik Indonesia. Laporan pengembangan HIV AIDS triwulan I-IV. Jakarta: Pusat Data dan Informasi Kementrian Kesehatan Republik Indonesia; 2015.

3. Kaufman MR, Cornish F, Zimmerman RS, Johnson BT. Health behavior change models for HIV prevention and AIDS care: practical recommendations for a multi-level approach. J Acquir Immune Deficiency Syndrome. 2014;66(3):250-8.

4. World Health Organization. Guidelines guideline on when to start antiretroviral therapy and on pre-exposure prophylaxis for HIV. Geneva;WHO Library Cataloguingin-Publication Data: 2015.

5. Hosseinipour MC, Kumarasamy N, Hakim JG, Mehendale S, Chariyalertsak S, Santos $B R$, et al. Prevention of HIV-1 infection with early antiretroviral therapy. N Engl J Med. 2011;365(6):493-505.

6. Liu H, Su Y, Zhu L, Xing J, Wu J, Wang N. Effectiveness of ART and condom use for prevention of sexual HIV transmission in serodiscordant couples: a systematic review and meta-analysis. PLoS One. 2014;9(11):1-7.

7. Kementrian Kesehatan Republik Indonesia. Peraturan Menteri Kesehatan Republik Indonesia Tentang Penanggulangan HIV dan AIDS. Jakarta: Peraturan Menteri Kementrian Kesehatan RI; 2013.

8. White JM, Mimiaga MJ, Krakower DS, Mayer $\mathrm{KH}$. Evolution of massachusetts physician attitudes, knowledge, and experience regarding the use of antiretrovirals for HIV prevention. AIDS Patient Care STDS. 2012;26(7):395-405.

9. Guadamuz TE, Cheung DH, Wei C, Koe S, Lim SH. Young, online and in the dark: scaling up HIV testing among MSM in ASEAN. PLoS One. 2015;10(5):1-12.

10. Stringer JSA, Zulu I, Levy J, Stringer EM, Mwango A, Chi BH, et al. Rapid Scale- 
up of Antiretroviral Therapy at Primary Care Sites in Zambia: feasibility and early outcomes. JAMA. 2006;296(7):782-93.

11. Tabi MM, Powell M, Hodnicki D. Use of traditional healers and modern medicine in Ghana. Int Nurs Rev. 2006;53(1):52-8.

12. Humphreys CP,Wright J, Walley J, Mamvura CT, Bailey KA, Ntshalintshali SN, et al. Nurse Led, primary care based antiretroviral treatment versus hospital care: A Controlled Prospective Study in Swaziland. BMC Health Serv Res. 2010;10(229):1-7.

13. Shuaib W, Iftikhar H, Alweis R, Shahid H. Warfarin Therapy: Survey of Patients' Knowledge of their Drug Regimen. Malays J Med Sci. 2014;21(4):37-41.

14. Waluyo A, Sukmarini L, Rosakawati R. Persepsi Pasien HIV/AIDS dan Keluarganya Tentang HIV/AIDS dan Stigma Masyarakat Terhadapnya. Jurnal Keperawatan Indonesia. 2006;10(1):16-23.

15. Shaluhiyah Z, Musthofa SB, Widjanarko B. Stigma masyarakat terhadap orang dengan HIV/AIDS. Jurnal Kesmas Nasional. 2015;09(4):333-9.

16. Phillips AN, Cambiano V, Nakagawa F, Brown AE, Lampe $F$, Rodger $A$, et al. Increased HIV incidence in men who have sex with men despite high levels of ARTinduced viral suppression: analysis of an extensively documented epidemic. PLoS One. 2013;8(2):1-8.

17. Marcus U, Hickson F, Weatherburn $P$, Furegato M, Breveglieri M, Berg RC, et al. Antiretroviral therapy and reasons for not taking it among men having sex with men (MSM)-Results from The Europian MSM Internet Survey (EMIS). PLoS One. 2015;10(3):1-13.

18. Baghianimoghaddam $\mathrm{MH}$, Forghani $\mathrm{H}$, Zolghadr R, Rahaii Z KP. Health Belief Model and HIV/AIDS among high school female students in Yazd, Iran. J Res Med Sci. 2010;15(3):189-90.

19. Mimiaga MJ, Goldhammer $\mathrm{H}$, Belanoff $\mathrm{C}$, Tetu AM, Mayer KH. Men who have sex with men: perceptions about sexual risk, HIV and sexually transmitted disease testing, and provider communication. Sex Transm Dis. 2007;34(2):113-9.

20. Crepaz N, Marks G, Liau A, Mullins MM, Aupont LW, Marshall KJ, et al. Prevalence of unprotected anal intercourse among HIV-diagnosed MSM in the United States: a meta-analysis. AIDS. 2009; 23(13):161729. 